\title{
ДИНАМІКА ПОКАЗНИКІВ ЦИТОЛІТИЧНОГО СИНДРОМУ ПІД ВПЛИВОМ СКЕЛЕТНОЇ ТРАВМИ В ПОЄДНАННІ 3 ГОСТРОЮ КРОВОВТРАТОЮ, УШКОДЖЕННЯМ ШКІРИ ТА ЕФЕКТИВНІСТЬ РRР-ТЕРАПІЇ
}

Вступ. Дорожній травматизм належить до актуальних проблем сучасного урбанізованого суспільства. Унаслідок дорожньо-транспортних пригод, крім уражень скелета, часто бувають ушкодження м'яких тканин, зокрема шкіри. Несвоєчасні діагностика та лікування цих ушкоджень часто призводять до зростання смертності. Перспективним методом регенерації ушкоджених тканин організму $є$ біотрансплантати на основі тромбоцитів (Platelet Rich Plasma (PRP) терапія), однак за умов поєднаної травми даний метод корекції вивчено недостатньо.

Мета дослідження - з'ясувати динаміку показників цитолітичного синдрому під впливом скелетної травми в поєднанні з гострою крововтратою, механічним ушкодженням шкіри та оцінити ефективність PRP-терапії.

Методи дослідження. Експерименти проведено на 186 нелінійних білих щурах-самцях масою 180-200 ح. У 1-й дослідній групі моделювали механічне ушкодження шкіри (на спинці тварини викроювали шкірний клапоть розміром 2×2 см). У 2-й дослідній групі моделювали скелетну травму, ускладнену гострою крововтратою. У 3-й дослідній групі ці ушкодження поєднували. У 4-й дослідній групі тваринам з поєднаною травмою по кутах рани внутрішньодермально вводили по 0,1 мл збагаченої тромбоцитами плазми. Через 3, 7, 14, 21 і 28 діб після нанесення травми щурів виводили з експерименту. В сироватці крові визначали аланін- і аспартатамітотрансферазну (АлАТ, АсAT) активність. Контрольну групу становили інтактні тварини.

Результати й обговорення. Дослідження показали, що нанесення механічної травми шкіри, порівняно з контролем, до 21-ї доби зумовлювало статистично вірогідне зростання АлАТ й АсАТ активності у сироватці крові. До 28-ї доби активність маркерів цитолізу знижувалася. Величина АсАТ активності у сироватці крові досягала рівня контролю, тоді як АлАТ активність продовжувала залишатися підвищеною. Аналогічною була і закономірність динаміки АлАТ й АсАТ активності за умов нанесення скелетної травми, ускладненої гострою крововтратою, однак з більшою амплітудою. Проте до 28-ї доби показники не досягали рівня контролю. Моделювання поєднаної травми супроводжувалося ще більшим посиленням процесів цитолізу в усі терміни експерименту. В результаті проведення PRP-терапії у групі щурів з поєднаною травмою, порівняно з травмованими тваринами без корекції, з 14-ї доби експерименту відмічали зниження АлАТ й АсАТ активності у сироватці крові.

Висновки. Механічне ушкодження шкірних покривів істотно поглиблює цитолітичний синдром, зумовлений скелетною травмою, ускладненою гострою крововтратою. Внутрішньодермальне введення збагаченої тромбоцитами алогенної плазми за цих умов сприяє зниженню інтенсивності процесів цитолізу, починаючи з 14-ї доби експерименту.

КЛЮЧОВІ СЛОВА: механічне ушкодження шкіри; скелетна травма; крововтрата; системні порушення; PRP-терапія.

ВСТУП. Актуальною проблемою сучасного урбанізованого суспільства продовжує залишатися травматизм. У структурі травми в останні роки зростає частота високоенергетичних уражень, що зумовлюють тяжкі множинні й поєднані ушкодження, які трактують як політравму. Через синдром взаємного обтяження такі травми характеризуються значною тяжкістю і високою летальністю [1].

Найчастішою причиною політравми в мирний час $€$ дорожній травматизм. Серед усіх травмо(c) 3. В. Смаглій, С. О. Галникіна, 2021. ваних у дорожньо-транспортних пригодах (ДТП) пацієнти з політравмою становлять понад $80 \%$ $[2,3]$. У зв'язку з цим, за статистикою ВООЗ, дорожньо-транспортний травматизм входить у п'ятірку провідних причин смерті у світі, а в структурі смертності осіб віком від 5 до 44 років - посідає перше місце.

Високоенергетична травма при дтП характеризується значним ступенем ушкодження різних органів та систем організму. Насамперед це стосується опорно-рухового апарату, внутрішніх органів, центральної нервової системи та, як 
правило, супроводжується зовнішньою або внутрішньою масивною крововтратою [4].

В окремих публікаціях зазначено, що внаслідок ДТП часто ушкоджуються м'які тканини, а саме відзначають їх відрив, при якому велика частина шкіри та підшкірної клітковини відокремлюється від підлеглої фрасції, м'язів або кісткової поверхні [5]. За даними [6], захворюваність, пов'язана з ушкодженням м'яких тканин, становить близько $4 \%$ й удвічі частіше виникає у чоловіків працездатного віку. Три чверті випадків - це травми, пов'язані з дорожньо-транспортними пригодами. Головними місцями ушкодження м'яких тканин є нижні кінцівки, тулуб, скальп і обличчя 3 різною втратою шкіри та м'яких тканин [7].

У клініці травми м'яких тканин в основному $€$ недооціненими ураженнями. Несвоєчасні діагностика та лікування цих ушкоджень часто призводять до некрозу повної товщини шкіри через порушення кровопостачання відірваного шкірного клаптя [8]. Більше того, у пацієнтів із тяжким перебігом ДТП може виникнути інорекція або навіть некротичний фрасціїт через неправильне лікування, що спричиняє високу захворюваність і смертність [9].

У зв'язку з цим, питання щодо відновлення шкірних покривів, стимуляції процесів репаративної регенерації шкіри є важливим компонентом лікування політравми та зниження інтенсивності її системних проявів.

Відомо, що тромбоцити відіграють важливу роль у загоєнні ушкоджених тканин організму [10]. Вони володіють достатньо високими репаративним і регенераторним потенціалами, які можуть бути використані для відновлення ушкоджених тканин [11]. При адгезії та руйнуванні тромбоцитів з альфра-гранул виділяється ряд фракторів росту (тромбоцитарний фрактор росту (PDGF), фрактор росту фрібробластів (FGF), трансорормуючий фрактор росту (TGF-ß1), інсуліноподібний фрактор росту (IGF-1), фрактор росту судин та ендотелію (VEGF, VGF)), які стимулюють гістіогенез, хемотаксис і диференціювання клітин [12].

Таким чином, є всі підстави вважати, що біотрансплантати на основі тромбоцитів (Platelet Rich Plasma (PRP) терапія) здатні значно прискорити регенерацію ушкоджених м'яких тканин, однак їх системний вплив за умов політравми вивчено недостатньо, що визначило необхідність проведення цього дослідження. Останнє тим більш важливе, що головною причиною смерті внаслідок політравми є розвиток поліорганної дисфункції і недостатності [1] з ураженням органів, віддалених від місця безпосереднього ушкодження. В основі патогенезу ураження лежать посилення процесів ліпідної пероксидації клітинних мембран з розвитком цитолітичного синдрому, посилення ендотоксикозу та зниження органозалежних фрункцій.

Мета дослідження - 3'ясувати динаміку показників цитолітичного синдрому під впливом скелетної травми в поєднанні 3 гострою крововтратою, механічним ушкодженням шкіри та оцінити еорективність PRP-терапії.

МЕТОДИ ДОСЛІДЖЕННЯ. Експерименти проведено на 186 нелінійних білих щурах-самцях масою 180-200 г. Усіх їх поділили на 5 груп: контрольну і 4 дослідних. Наносили травми за умов тіопентал-натрієвого наркозу в дозі 40 мг/кг маси тварини. До контрольної групи ввійшли інтактні щури, яких тільки вводили в наркоз. У 1-й дослідній групі тваринам моделювали механічне ушкодження шкіри. На депільованій поверхні спинки щура наносили механічне ушкодження шкіри. Вирізали шкірний клапоть разом із підшкірно-жировою клітковиною розміром $2 \times 2$ см. У 2-й дослідній групі тваринам моделювали скелетну травму, ускладнену гострою крововтратою. Шляхом однократного дозованого удару викликали закритий перелом стегнової кістки та моделювали гостру крововтрату зі стегнової вени (20 \% об'єму циркулюючої крові). У 3-й дослідній групі ці ушкодження поєднували. У 4-й дослідній групі тваринам з поєднаною травмою проводили PRP-терапію із застосуванням збагаченої тромбоцитами алогенної плазми. Останню заготовляли за методом M. R. Messora та ін. (2011) [13]. Отриману таким чином збагачену тромбоцитами галогенну плазму вводили внутрішньодермально по 0,1 мл на стандартну глибину по кутах рани на відстані не більше 5 мм від її краю. У контрольній групі щурам аналогічно вводили фрізіологічний розчин. Рану покривали асептичною пов'язкою, а через 3 доби вели відкритим способом. Маркером системного впливу модельованих травм став показник цитолітичного синдрому - аланін- і аспартатамітотрансореразна (АлАТ, АсАТ) активність у сироватці крові через 3, 7, 14, 21 і 28 діб після нанесення травми, яку визначали уніфікованим методом для аналізатора біохімічного "Humalyzer 2000".

Усі експерименти виконували відповідно до загальних правил і положень Європейської конвенції про захист хребетних тварин, що використовуються для дослідних та інших наукових цілей (Страсбург, 1986), Загальних етичних принципів експериментів на тваринах (Київ, 2001), Закону України "Про захист тварин від жорстокого поводження" (2006, додаток 4), а також Науково-практичних рекомендацій з утримання лабораторних тварин та роботи з ними. 
Вірогідність відмінностей між експериментальними групами оцінювали з використанням непараметричного критерію Манна - Уїтні.

РЕЗУЛЬТАТИ Й ОБГОВОРЕННЯ. ДосліДЖеНня показали (рис. 1), що під впливом травми м'яких тканин АлАТ активність, порівняно 3 контролем, статистично вірогідно зростала вже через 3 доби експерименту (на 89,3 \%, p<0,05), досягала максимуму через 7 діб (у 2,08 раза, $\mathrm{p}<0,05)$, далі змінювалася хвилеподібно зі зниженням через 14 діб і повторним підвищенням через 21 добу (в 2,04 раза, p<0,05). До 28-ї доби показник зменшувався, проте на 38,8 \% залишався більшим від контролю $(p<0,05)$. Після нанесення скелетної травми, ускладненої гострою крововтратою, динаміка АлАТ активності у сироватці крові була аналогічною, проте з більшою амплітудою. Через 35 діб показник теж знижувався, проте перевищував контроль у 2,01 раза $(p<0,05)$. Моделювання поєднаної травми супроводжувалося найбільшим зростанням АлАТ активності у сироватці крові: через 3 доби - у 2,66 раза, через 7 діб - у 3,05 раза. Практично на такому ж рівні показник перебував до 21-ї доби (p>0,05) та знижувався до 28-ї доби. У цей термін показник перевищував рівень контролю у 2,54 раза $(p<0,05)$.

Порівняння дослідних груп показало (табл. 1), що в усі терміни посттравматичного періоду зі зростанням тяжкості ураження підвищувалась і АлАТ активність у сироватці крові $\left(\mathrm{p}_{1-2}<0,05\right.$; $\left.\mathrm{p}_{1-3}<0,05 ; \mathrm{p}_{2-3}<0,05\right)$. У динаміці в 1-й і 2-й дослідних групах характерним був період тимчасового зниження - через 14 діб з повторним зростанням через 21 добу, тоді як у 3-й дослідній групі показник збільшувався до 7-ї доби, залишався на такому ж рівні до 21-ї доби та зменшувався до 28-ї доби.

У результаті проведення PRP-терапії (рис. 2), починаючи з 14-ї доби експерименту, відмічали істотне зниження АлАТ активності у сироватці крові: через 14 діб - на 17,0 \% (p<0,05), через 21 добу - на 25,0 \% ( $p<0,05)$, через 28 діб - на $23,2 \%(p<0,05)$.

Аналіз динаміки АсАТ активності у сироватці крові показав (рис. 3), що під впливом ушкодження м'яких тканин вона теж суттєво зростала порівняно з контролем, починаючи з 3-ї доби експерименту (на 40,5 \%, p<0,05). У подальшому динаміка показника була двофазовою 3 досягненням першого максимуму через 7 діб (на $56,5 \%, p<0,05$ ) і другого - через 21 добу (на $58,8 \%, p<0,05)$. До 28-ї доби він знижувався та досягав рівня контрольної групи ( $>>0,05)$. Після нанесення скелетної травми, ускладненої гострою крововтратою, динаміка АсАТ активності у сироватці крові була аналогічною, проте з більшою амплітудою. До 21-ї доби показник теж зменшувався, проте не досягав рівня контролю

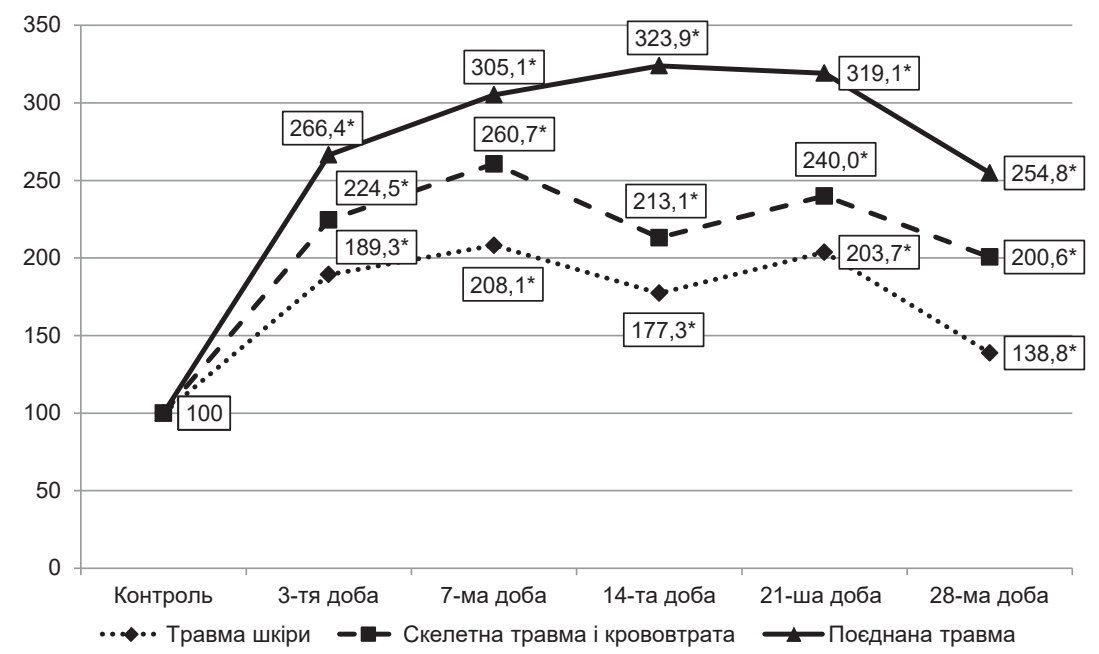

Рис. 1. Динаміка аланінамінотрансферазної активності у сироватці крові, зумовленої поєднаною травмою (у відсотках до рівня контролю).

Примітка. Тут і на рисунку 3: * - відмінності стосовно контрольної групи статистично вірогідні $(\mathrm{p}<0,05)$.

Таблиця 1 - Вірогідність відмінностей аланінамінотранссреразної активності у сироватці крові під впливом поєднаної травми в різні терміни посттравматичного періоду

\begin{tabular}{||c|c|c|c|c|c||}
\hline $\begin{array}{c}\text { Термін після нанесення } \\
\text { травми, доба }\end{array}$ & 3-тя & 7-ма & 14-та & 21-ша & 28-ма \\
\hline $\mathrm{p}_{1-2}$ & $<0,05$ & $<0,05$ & $<0,05$ & $<0,05$ & $<0,05$ \\
\hline $\mathrm{p}_{1-3}$ & $<0,05$ & $<0,05$ & $<0,05$ & $<0,05$ & $<0,05$ \\
\hline $\mathrm{p}_{2-3}$ & $<0,05$ & $<0,05$ & $<0,05$ & $<0,05$ & $<0,05$ \\
\hline
\end{tabular}




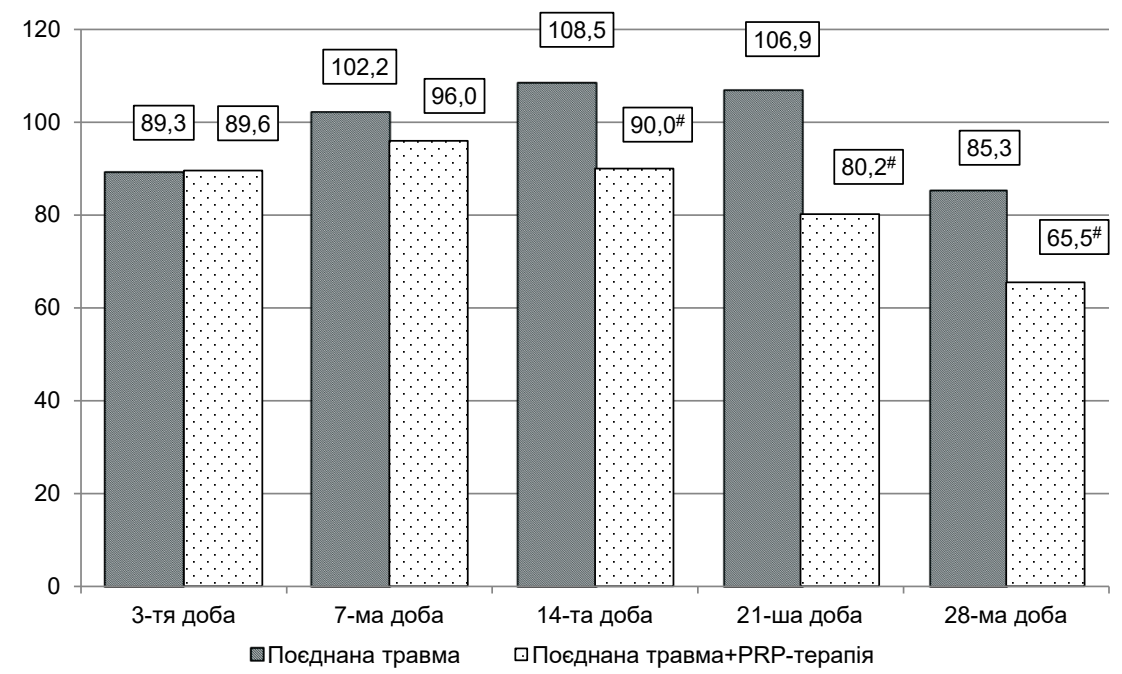

Pис. 2. Вплив PRP-терапії на динаміку аланінамінотранссреразної активності у сироватці крові, зумовленої поєднаною травмою (у відсотках до рівня контролю).

Примітка. Тут і на рисунку 4: \#- відмінності стосовно групи тварин з поєднаною травмою без корекції статистично вірогідні $(\mathrm{p}<0,05)$.

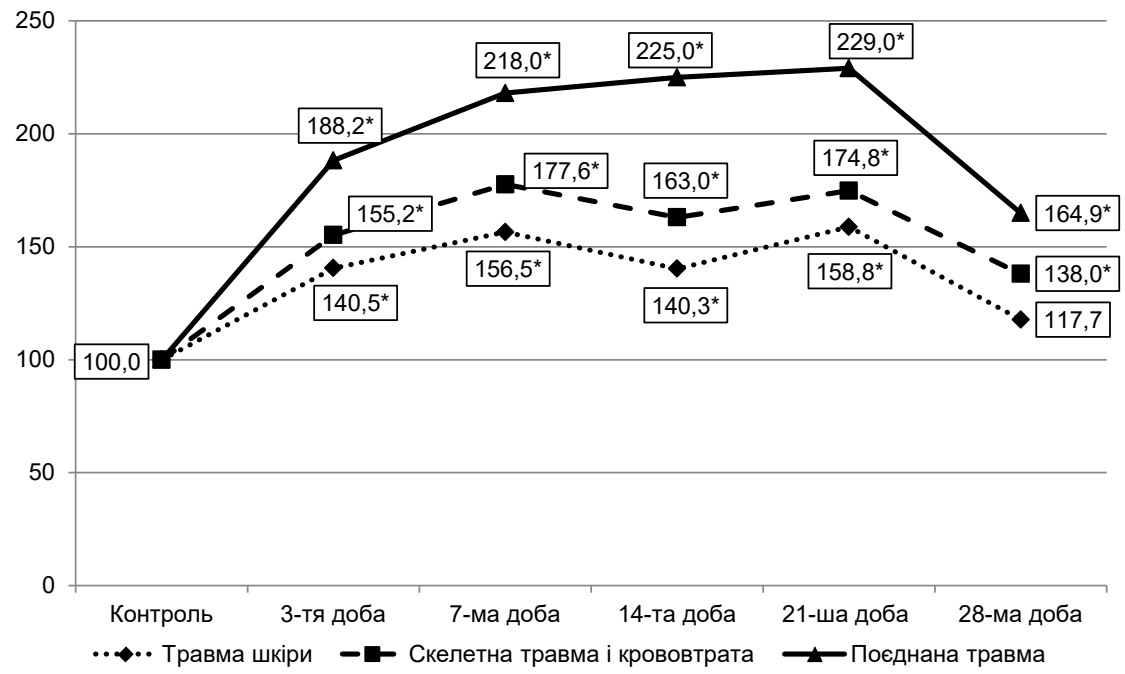

Рис. 3. Динаміка аспартатамінотранссреразної активності у сироватці крові, зумовленої поєднаною травмою (у відсотках до рівня контролю).

і був на 38,0 \% більшим $(p<0,05)$. Аналогічно зростала й АсАТ активність у сироватці крові після моделювання поєднаної травми. Через 7 діб показник досягав максимуму (в 2,18 раза перевищував рівень контролю, $р<0,05)$ і залишався на такому ж рівні до 21-ї доби ( $>>0,05)$. У подальшому він знижувався, проте на 64,9\% був більшим від контролю $(p<0,05)$.

Порівняння дослідних груп між собою показало (табл. 2), що, починаючи із 7-ї доби, зі збільшенням тяжкості травми зростала й АсАТ активність у сироватці крові $\left(\mathrm{p}_{1-2}<0,05 ; \mathrm{p}_{1-3}<0,05\right.$; $\left.\mathrm{p}_{2-3}<0,05\right)$. Через 3 доби експерименту величина досліджуваного показника в 1-й і 2-й дослідних групах була практично однаковою $\left(p_{1-2}>0,05\right)$, проте в 3-й дослідній групі АсАТ активність статистично вірогідно перевищувала таку в 1-й і 2-й дослідних групах $\left(\mathrm{p}_{1-3}<0,05\right.$; $\left.\mathrm{p}_{2-3}<0,05\right)$.

Таким чином, нанесення механічної травми шкіри зумовлює посилення процесів цитолізу в організмі піддослідних тварин, що супроводжується збільшенням АлАТ й АсАТ активності у сироватці крові. Динаміка досліджуваних показників була хвилеподібною з першим максимумом через 7 діб, періодом тимчасового благополуччя через 14 діб і повторним зростанням через 21 добу. В усі ці терміни показники статистично вірогідно перевищували такі в контрольній групі. До 28-ї доби активність маркерів цитолізу знижувалася. Величина АсАТ активності у сироватці крові досягала рівня контролю, тоді як АлАТ активність продовжувала залишатися підвищеною. Аналогічною була і закономірність динаміки 
Таблиця 2 - Вірогідність відмінностей аспартатамінотрансферазної активності у сироватці крові під впливом поєднаної травми в різні терміни посттравматичного періоду

\begin{tabular}{||c|c|c|c|c|c||}
\hline $\begin{array}{c}\text { Термін після нанесення } \\
\text { травми, доба }\end{array}$ & 3-тя & 7-ма & 14-та & 21-ша & 28 -ма \\
\hline $\mathrm{p}_{1-2}$ & $>0,05$ & $<0,05$ & $<0,05$ & $<0,05$ & $<0,05$ \\
\hline $\mathrm{p}_{1-3}$ & $<0,05$ & $<0,05$ & $<0,05$ & $<0,05$ & $<0,05$ \\
\hline $\mathrm{p}_{2-3}$ & $<0,05$ & $<0,05$ & $<0,05$ & $<0,05$ & $<0,05$ \\
\hline
\end{tabular}

АлАТ й АсАТ активності за умов нанесення скелетної травми, ускладненої гострою крововтратою, однак з більшою амплітудою. До 28-ї доби обидва показники не досягали рівня контролю. Враховуючи подібну закономірність у динаміці АлАТ й АсАТ активності у сироватці крові, можна припустити, що в основі посилення процесів цитолізу як після ураження м'яких тканин шкіри, так і після нанесення скелетної травми, ускладненої гострою крововтратою, лежить вторинне ураження внутрішніх органів, зокрема печінки [2, 3]. Останнє, імовірно, зумовлює системний вплив прозапальних чинників, які утворюються внаслідок травмування. Пусковим механізмом вважають порушення мікроциркуляції з розвитком гіпоксії, утворенням активних фрорм оксигену та активацією процесів пероксидації ліпідів і протеїнів клітинних мембран, що сприяє посиленню їх проникності й надходженню у кров цитоплазматичних ензимів [14]. Важливо відмітити, що ця закономірність характерна як для ушкодження шкіри, так і для скелетної травми, ускладненої гострою крововтратою, що свідчить про вагому роль травми шкіри в патогенезі системних порушень організму. Останнє підтверджує ще більше посилення процесів цитолізу за умов поєднаної травми. В основі виявленого феномену, очевидно, лежить есрект взаємного обтяження, зумовленого сумацію системного ушкоджуваль- ного впливу шкіри, скелетної травми та гострої крововтрати [14].

У результаті проведення PRP-терапії в групі щурів з поєднаною травмою, порівняно 3 травмованими тваринами без корекції, 3 14-ї доби експерименту відмічали зниження у сироватці крові АлАТ й АсАТ активності (рис. 4). Отриманий результат свідчить про виражений системний вплив застосованого методу корекції, який, на наш погляд, реалізується двома механізмами: перший - зумовлений прискоренням загоєння травмованої ділянки шкіри і зменшенням її патогенної ролі у вторинному ураженні внутрішніх органів, другий - пов'язаний із протекцією вторинного ураження внутрішніх органів внаслідок впливу тромбоцитарних фракторів росту, які можуть потрапити в системний кровотік [12].

Таким чином, механічне ушкодження шкірних покривів здатне викликати виражені системні порушення, що проявляються активацією процесів цитолізу. Наявність ураження шкіри істотно поглиблює цитолітичний синдром, зумовлений скелетною травмою, ускладненою гострою крововтратою. Усе це вказує на вагому роль ураження шкіри у проявах травматичної хвороби. За даних умов внутрішньодермальне введення збагаченої тромбоцитами алогенної плазми сприяє зниженню інтенсивності процесів цитолізу, починаючи з 14-ї доби експерименту, це свідчить про вагому роль PRP-терапії у зниженні

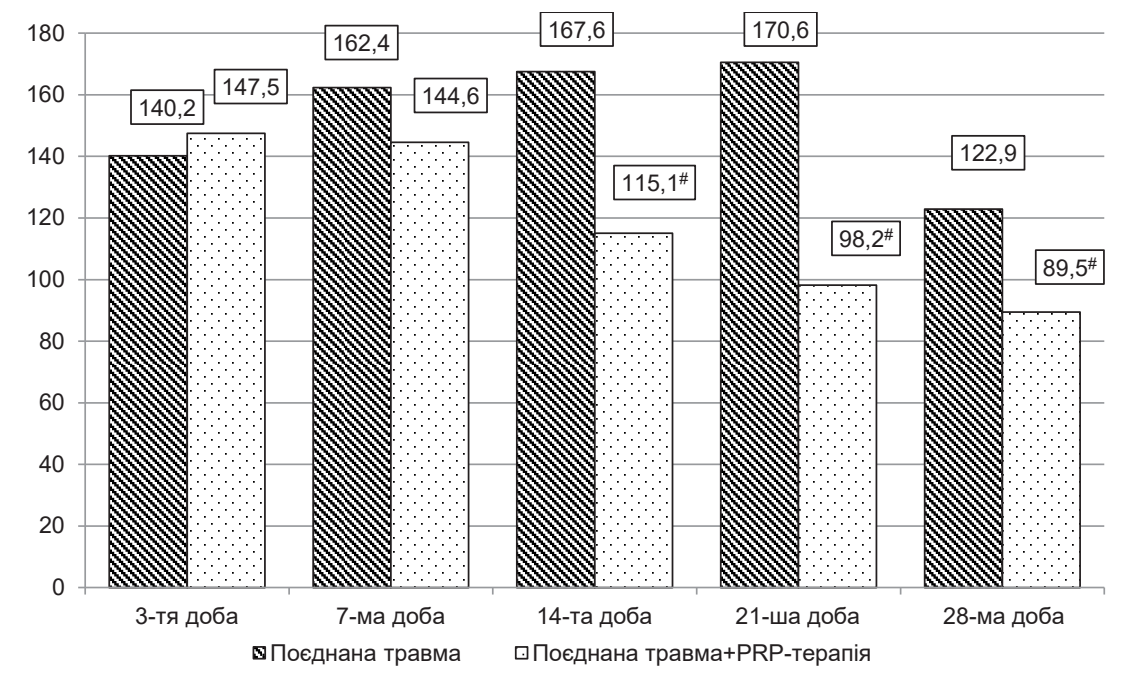

Рис. 4. Вплив PRP-терапії на динаміку аспартатамінотрансфреразної активності у сироватці крові, зумовленої поєднаною травмою (у відсотках до рівня контролю). 
системних проявів поєднаної травми, що вимагає подальшого поглибленого вивчення.

ВИСНОВКИ. 1. Механічне ушкодження шкіри викликає посилення процесів цитолізу в організмі піддослідних тварин, що проявляється активацією у сироватці крові АлАТ і АсАТ, яка за величиною АлАТ не стихає до 28-ї доби експерименту.

\section{СПИСОК ЛІТЕРАТУРИ}

1. Гур'єв С. О. Аналіз безпосередіх причин смерті у постраждалих із політравмою та пошкодженням скелета / С. О. Гур'єв, А. Ю. Філь, О. М. Танасієнко // Травма. - 2015. - 16, № 4. - С. 7-10.

2. Котельников Г. П. Политравма: современное состояние проблемы (обзор литературы) / Г. П. Котельников, И. Г. Труханова, А. Ю. Шабанова // Врач скорой помощи. - 2014. - № 12. - С. 4-10.

3. Pfeifer R. Diagnostics and treatment strategies for multiple trauma patients // R. Pfeifer, H. C. Pape // Chirurg. - 2016. - 87, Issue 2. - P. 165-173.

4. Состояние дорожно-транспортного травматизма по данным официальной медицинской статистики / Е. П. Какорина, Т. М. Андреева, А. В. Поликарпов [и др.] // Проблемы соц. гигиены, здравоохранения и истории медицины. - 2015. - № 6. - С. 18-24.

5. Arnez Z. Classification of soft-tissue degloving in limb trauma / Z. Arnez, U. Khan, M. Tyler // J. Plast. Reconstr. Aesthet. Surg. - 2010. - 63, Issue 11. P. $1865-1869$

6. Patterns and management of degloving injuries: a single national level 1 trauma center experience / H. Suhail, Kh. Ahmed, El-M. Ayman [et al.] // World J. Emerg. Surg. - 2016. - 11, Issue 35. DOI: 10.1186/ s13017-016-0093-2.

7. Wójcicki P. Severe lower extremities degloving injuries-medical problems and treatment results / P. Wójcicki, W. Wojtkiewicz, P. Drozdowski // Pol. Przegl. Chir. - 2011. - 83, Issue 5. - P. 276-282.

\section{REFERENCES}

1. Huriev, S.O., Fil, A.Yu., \& Tanasienko, O.M. (2015). Analysis of immediate causes of death in victims with polytrauma and skeletal damage. Trauma, 16 (4), 7-10 [in Ukrainian].

2. Kotelnikov, G.P., Trukhanova, I.G., \& Shabanova, A.Yu. (2014). Polytrauma: current state of the problem (literature review). Emergency Doctor, 12, 4-10 [in Russian].

3. Pfeifer, R., \& Pape, H.C. (2016). Diagnostics and treatment strategies for multiple trauma patients. Chirurg, 87 (2), 165-173. DOI: 10.1007/s00104-015-0139-0.

4. Kakorina, E.P., Andreeva, T.M., Polikarpov, A.V., \& Ogryzko, E.V. (2015). The state of traffic traumatism according data of official medical statistics. Problems of
2. Нанесення механічного ушкодження шкіри суттєво поглиблює цитолітичний синдром, спричинений скелетною травмою, ускладненою гострою крововтратою. Внутрішньодермальне введення на цьому тлі збагаченої тромбоцитами алогенної плазми значно знижує прояви цитолітичного синдрому, зумовленого поєднаною травмою, починаючи з 14-ї доби експерименту.

8. The management of degloving injury of lower extremities: technical refinement and classification / H. Yan, W. Gao, Z. Li [et al.] // J. Trauma Acute Care Surg. - 2013. - 74, Issue 2. - P. 604-610.

9. The therapeutic challenges of degloving soft-tissue injuries / R. Latifi, H. El-Hennawy, A. El-Menyar [et al.] // J. Emerg. Trauma Shock. -2014. - 7, Issue 3. - P. 228-232.

10. Clinical indications and treatment protocols with platelet-rich plasma in dermatology. Conde Montero $\mathrm{E}$ : PRP in wound healing / R. Alves, R. Grimalt, eds. Barcelona, Ediciones Mayo, 2016. - P. 59-72.

11. Ozdemir B. Treatment of intrabony defects with betatricalciumphosphate alone and in combination with plateletrich plasma / B. Ozdemir, E. J. Okte // BioMed. Mater. Res. B. Appl. Biomater. - 2012. - 100, Issue 4. P. 976-983.

12. Lacci K. M. Platelet-rich Plasma: support for its use in wound healing / K. M. Lacci, A. Dardik // Yale J. Biol. Med. - 2010. - 83, Issue 1. - P. 1-9.

13. A standardized research protocol for platelet-rich plasma (PRP) preparation in rats / M. R. Messora, M. J. H. Nagata, F. A. C. Furlaneto [et al.] // RSBO. 2011. - 8, Issue 3. - P. 299-304.

14. Гудима А. А. Антиоксидантно-прооксидантний та цитокіновий баланс у пізній період комбінованої травми в експерименті / А. А. Гудима, Т. В. Кащак, К. В. Шепітько // Світ медицини та біології. - 2019. № 1 (67). - C. 42-47.

Social Hygiene, Public Health and History of Medicine, 6, 18-24 [in Russian].

5. Arnez, Z., Khan, U., \& Tyler, M. (2010). Classification of soft-tissue degloving in limb trauma. J. Plast. Reconstr. Aesthet. Surg., 63 (11), 1865-1869. DOI: 10.1016/j. bjps.2009.11.029.

6. Hakim, S., Ahmed, K., El-Menyar, A., Jabbour, G., Peralta, R., Nabir, S., ..., \& Al-Thani, H. (2016). Patterns and management of degloving injuries: a single national level 1 trauma center experience. World J. Emerg. Surg., 11, 35. DOI: 10.1186/s13017-016-0093-2.

7. Wójcicki, P., Wojtkiewicz, W., \& Drozdowski, P. (2011). Severe lower extremities degloving injuries- 
medical problems and treatment results. Pol. Przegl. Chir., 83 (5), 276-282. DOI: 10.2478/v10035-011-0043-3.

8. Yan, H., Gao, W., Li, Z., Wang, C., Liu, S., Zhang, F., \& Fan, C. (2013). The management of degloving injury of lower extremities: technical refinement and classification. J. Trauma Acute Care Surg., 74 (2), 604610. DOI: 10.1097/TA.0b013e31827d5e00.

9. Latifi, R., El-Hennawy, H., El-Menyar, A., Peralta, R., Asim, M., Consunji, R., \& Al-Thani, H. (2014). The therapeutic challenges of degloving soft-tissue injuries. J. Emerg. Trauma Shock, 7 (3), 228-232. DOI: 10.4103/0974-2700.136870.

10. Alves, R., \& Grimalt, R. (Eds.). (2016). Clinical indications and treatment protocols with platelet-rich plasma in dermatology. Conde Montero E: PRP in wound healing. Barcelona, Ediciones Mayo.

11. Ozdemir, B., \& Okte, E.J. (2012). Treatment of intrabony defects with betatricalciumphosphate alone and in combination with plateletrich plasma. Biomed. Mater. Res. B. Appl. Biomater., 100 (4), 976-983. DOI: $10.1002 / \mathrm{jbm}$. b.32660.

12. Lacci, K.M., \& Dardik, A. (2010). Platelet-rich Plasma: support for its use in wound healing. Yale J. Biol. Med., 83 (1), 1-9.

13. Messora, M.R., Hitomi Nagata, M.J., Chaves Furlaneto, F.A., Menegati Dornelles, R.C., Mogami Bomfim, S.R., Deliberador, T.M., ..., \& Bosco, A.F. (2011). A standardized research protocol for platelet-rich plasma (PRP) preparation in rats. RSBO, 8 (3), 299-304.

14. Hudyma, A.A., Kashchak, T.V., \& Shepitko, K.V. (2019). Antioxidant-prooxidant and cytokine balance in the late period of combined trauma in the experiment. World of Medicine and Biology, 1 (67), 42-47. DOI: 10.26724/2079-8334-2019-1-67-42 [in Ukrainian].

\section{DYNAMICS OF CYTOLYTIC SYNDROME INDICES UNDER THE INFLUENCE OF SKELETAL TRAUMA IN COMBINATION WITH ACUTE BLOOD LOSS, SKIN DAMAGE AND PRP-THERAPY EFFECTIVENESS}

Summary
Introduction. Road injuries are among the topical issues of modern urban society. Road accidents often cause soft tissue damage, including skin damage, in addition to skeletal traumas. Improper diagnosis and treatment of these injuries often leads to an increase in mortality. One of the promising methods of regeneration of the damaged body tissues is platelet-based biological grafts (Platelet Rich Plasma (PRP) therapy), but in the case of multiple trauma, this method of correction is insufficiently studied.

The aim of the study - to determine the dynamics of cytolytic syndrome indices under the influence of multiple trauma and evaluate the PRP-therapy effectiveness.

Research Methods. The experiments were performed on 186 nonlinear white male rats weighing 180-200 g. In the first experimental group, the animals were simulated mechanical damage of skin (on the back of the animal a skin flap of $2 \times 2 \mathrm{~cm}$ was cut). In the second experimental group, skeletal trauma complicated with acute blood loss was simulated. In the third experimental group, these lesions were combined. In the fourth experimental group, animals with multiple trauma were intradermally injected with $0.1 \mathrm{ml}$ of platelet-rich plasma in wound edges. After $3,7,14,21$ and 28 days of trauma infliction, the animals were removed from the experiment. The serum values of alanine and aspartate aminotransferase activities (ALT, AST) were measured. The control groups consisted of intact animals.

Results and Discussion. The studies showed that mechanical trauma of skin causes statistically significant increase in serum values of ALT and AST activities up to 21st day compared to the control. By the 28th day, the activity of cytolysis markers decreased. Serum AST reached the control level, while ALT activity continued to be elevated. The regularity of ALT and AST dynamics under conditions of skeletal trauma complicated with acute blood loss, but with greater amplitude, was similar. By the 28th day, both indicators did not reach the control level. The multiple trauma model was accompanied by an even greater intensification of cytolysis processes at all experimental periods. Due to use of PRP-therapy in the group with multiple trauma compared to injured animals without correction from the 14th day of the experiment, there was a decrease in serum ALT and AST activity.

Conclusions. Mechanical damage of skin considerably exacerbates the cytolytic syndrome caused by skeletal trauma complicated by acute blood loss. Intradermal administration of allogeneic platelet-rich plasma under these conditions leads to decrease in the intensity of cytolysis processes, starting from the 14th day of the experiment.

KEY WORDS: mechanical damage to the skin; skeletal trauma; blood loss; systemic disorders; PRP therapy.

Отримано 17.11.21

Адреса для листування: 3. В. Смаглій, Тернопільський національний медичний університет імені І. Я. Горбачевського мОз України, майдан Волі, 1, Тернопіль, 46001, Україна, e-mail: smagliyzv@tdmu.edu.ua. 